NBER WORKING PAPER SERIES

\title{
THE MEASURED BLACK-WHITE WAGE GAP AMONG WOMEN IS TOO SMALL
}

\author{
Derek Neal \\ Working Paper 9133 \\ http://www.nber.org/papers/w9133 \\ NATIONAL BUREAU OF ECONOMIC RESEARCH \\ 1050 Massachusetts Avenue \\ Cambridge, MA 02138 \\ September 2002
}

I thank workshop participants at Harvard University, Syracuse University, the University of Michigan, Northwestern University, Princeton University, SITE and the University of Texas at Dallas for helpful comments on previous drafts of this paper. I owe special thanks to Josh Angrist, Fran Blau, James Heckman, Bo Honore, John Kennan, Alan Krueger, Larry Katz, Kevin Lang, Bruce Meyer, Chris Taber, and Dan O'Brien for helpful comments and discussions. I also thank participants at the University of Chicago Conference in memory of Sherwin Rosen and the Labor Studies session held at the 2001 NBER Summer Institute to honor Sherwin's memory. I thank the Institute for Research on Poverty, the Center for Demography and Ecology at the University of Wisconsin for research support. I also appreciate support from the Alfred P Sloan Foundation through the Sloan Faculty Research Fellowship. I thank Nathaniel BaumSnow, Brian Bucks and Sarah Hamersma for research assistance. I thank the National Science Foundation for support. The views expressed in this paper are those of the authors and not necessarily those of the National Bureau of Economic Research.

(C) 2002 by Derek Neal. All rights reserved. Short sections of text, not to exceed two paragraphs, may be quoted without explicit permission provided that full credit, including (C) notice, is given to the source. 
The Measured Black-White Wage Gap Among Women is Too Small

Derek Neal

NBER Working Paper No. 9133

September 2002

JEL No.J3, J7

\section{$\underline{\text { ABSTRACT }}$}

Taken as a whole, the literature on black-white wage inequality suggests that racial gaps in potential wages are much larger among men than women, and further that one can accurately assess black-white gaps in potential wages among women without accounting for black-white differences in patterns of female labor supply.

This paper challenges both pieces of this conventional wisdom. I provide several estimates of the black-white gap in potential wages for the year 1990 using data from the National Longitudinal Survey of Youth (NLSY), a panel data set that includes persons born between 1957 and 1964. I exploit data on wages and income sources for years before and after 1990 to develop imputation methods that allow me to adjust measures of the black-white wage gap among women for racial differences in selection patterns. Among young adult employed women in 1990, the Census, Current Population Surveys, and NLSY data yield median log wage gaps of -.11, -16, and -.18 respectively. Based on several different imputation procedures, I estimate that the median black-white gap in log potential wages among women in the NLSY is approximately -.25 .

Derek Neal

Department of Economics

University of Chicago

1126 E. 59th St.

Chicago, IL 60637

and NBER

d-neal@uchicago.edu 
In 1990, the United States Commission on Civil Rights issued a report entitled The Economic Status of Black Women. The report relies mainly on data from the 1980 Census although some calculations reflect data drawn from Current Population Surveys in the late 1980s. The report notes that the main sources of economic inequality between black and white women are not differences in labor market opportunities but rather significant differences in total family income that arise from large differences in the earnings and employment opportunities of black and white men. The report shows that, among employed women, overall black-white wage differences were quite small in 1980, and among those with at least a high school education, black women earned more than their white counterparts. ${ }^{1}$

The findings in the Commission's report are representative of the existing literature on black-white wage inequality among women. Although the wages of black women have fallen relative to those of white women over the past two decades, black-white wage gaps among working women remain quite small compared to the corresponding gaps among men. Further, a substantial literature concludes that black-white gaps in potential wages among men are likely much larger in absolute value than the observed gaps in measured wages. ${ }^{2}$ The employment rates of black men relative to white men fell throughout the 1970s and 1980s, and numerous studies indicate that racial differences in selection bias generate measured wage gaps that overstate the relative economic standing of black men. In contrast, overall labor force participation rates for black and white women have been quite similar for decades, and this fact underlies the commonly held view that selection bias does not contaminate measured black-white wage gaps among women. Taken as a whole, the literature on black-white wage inequality suggests that racial gaps in potential wages are much larger among men than women, and further that one can accurately assess black-white gaps in potential wages among women without

${ }^{1}$ Among college educated women, the black-white wage ratio in the 1980 census is 1.13 . The comparable figure from the 1980 March CPS is 1.02. See Table 4.6 on page 39 in the report. The sample used for these calculations includes women aged 25-64.

2 Recently, Chandra (2000), Heckman, Lyons and Todd (2000) as well as Kitamura, Johnson, and Neal (2000) all demonstrate that black-white wage gaps based on reported wages may be significantly smaller than corresponding gaps in potential wages. Earlier studies that address this question include Butler and Heckman (1977), Brown (1984), Heckman and Donohue (1991), and Smith and Welch (1989). 
accounting for black-white differences in patterns of female labor supply. ${ }^{3}$

This paper challenges both pieces of this conventional wisdom. First, even though participation rates are the same among black and white women, selection bias is still an important concern when estimating black-white gaps in potential wages because relationships between labor force participation and family structure differs notably by race. Married women who are raising children account for a disproportionate share of white women who do not work in the market, and a noteworthy number of these women are married to men who earn relatively high incomes. One might suspect that the decision by these women to work at home does not necessarily reflect low wage offers but rather high shadow prices of time spent at home. On the other hand, among black women, single mothers are over-represented in the sample of women who do not report any market work, and a significant fraction of black, single mothers who do not work in the market over multi-year periods are receiving means tested government assistance in some form. Such programs are not attractive options for women who can command high wages for market work, and it seems reasonable to conclude that these single mothers would earn relatively low wages if they chose market work. Thus, relationships between family structures, income sources, and participation behavior suggest that standard measures of black-white wage gaps among women are likely contaminated by selection bias.

Further, because previous studies ignore the potential effects of selection bias on measures of racial wage inequality among women, the existing literature exaggerates the extent of gender differences in black-white wage inequality. In the analyses below, I provide several estimates of the black-white gap in potential wages for the year 1990 using data from the

${ }^{3}$ Few studies explore reasons for the gender difference in black-white wage gaps and almost none explore the impact of selection bias among women. Bayard, Hellerstein, Neumark and Troske (1999) take conventional wage gap measures as a starting point and argue that gender differences in occupational segregation may account for a portion of the observed gender difference in the magnitude of the black white wage gap. Blau and Beller (1992) do address selection bias and racial wage inequality among women. However, their results are not directly comparable to those presented here because they address a slightly different question. They produce estimated black-white wage gaps for women in 1981 and 1988 that they interpret as estimates of what the gap in measured wages would have been in these years if participation patterns from 1971 had prevailed throughout the 1971-88 period. 
National Longitudinal Survey of Youth (NLSY), a panel data set that includes persons born between 1957 and 1964. I exploit data on wages and income sources for years before and after 1990 to develop imputation methods that allow me to adjust measures of the black-white wage gap among women for racial differences in selection patterns. These imputation rules yield a 1990 wage measure for at least 95 percent of both the black and white women in the NLSY sample, and the results suggest that selection bias does contaminate standard measures of blackwhite wage inequality among women.

Among young adult employed women in 1990, the Census, Current Population Surveys (CPS), and NLSY data yield median log wage gaps of $-.11,-16$, and -.18 respectively. These baseline differences among the samples highlight the potential impact of selection bias on these measured gaps. Because the NLSY contains more extensive questions about earnings and employment histories, it contains 1990 wage information for a larger fraction of the sample, and this difference in coverage appears to be a key reason that measured wage gaps are larger in the NLSY data. Further, even the -.18 gap in the NLSY appears to understate the true extent of black-white differences in labor market opportunities. Based on several different imputation procedures, I estimate that the median black-white gap in log potential wages among women in the NLSY is approximately -.25 . This gap is still smaller than the comparable gap among men, ${ }^{4}$ but it is almost $40 \%$ larger than the gap observed among women who report 1990 market wages in the NLSY and more than twice as large as the baseline gap among women in census data.

The next section outlines data on family structure and participation by race. Section 2 presents baseline results from the NLSY, Census, and CPS. Section 3 describes results from several imputation exercises involving NLSY data. Section 4 presents a simple analysis of marriage markets and labor supply that illustrates how black-white differences in marriage market opportunities necessarily complicate the measurement of racial wage gaps of among women. Section 5 discusses changes in black-white wage gaps over time. The conclusion

${ }^{4}$ I use data from the Census, CPS, and NLSY to estimate the black-white gap in log median potential wages among young adult men in 1990. Using a common imputation method, I find that the estimated gap varies between -.33 and -.37 among the three data sets. The estimates are comparable to other estimates in the literature. 
discusses future research.

\section{Participation Patterns}

Table 1 describes trends in two measures of labor force participation. Both measures are constructed using census data from the PUMS. The "in labor force" column captures whether or not respondents were working or seeking employment at the time they completed the census form. The full-time, full-year category measures the fraction of women who usually worked at least 35 hours per week and also worked at least 48 weeks in the previous calendar year.

In 1990, participation rates among black women were quite similar to those of white women, but in recent analyses of wage data for men, researchers have devoted considerable attention to the fact that participation rates among black men have fallen notably since 1970 . Chandra (2000) reports that the participation rate in 1990 among black men age 25-55 was only 83.5, compared to a corresponding rate of 93.7 among white men. Chandra and others argue that measured black-white wage gaps for men understate the degree of black-white inequality because a significant fraction of black men who face low wage offers do not participate and therefore do not report wages. Chandra also asserts that selection bias should not be a major concern in measuring black-white wage gaps among women because participation rates for women differ little by race in $1990 .^{5}$

Tables $2 \mathrm{a}$ and $2 \mathrm{~b}$ present more detailed data on participation patterns for women. The entries in these tables indicate the fraction of women of a given race and labor force status who occupy a particular family structure. If family structures had no impact on labor supply decisions, the prevalence of a given family structure among employed and non-employed women would be the same, and the entries on the left hand side of the tables would match those on the right. However, family structures are related to labor force participation rates, and these relationships differ by race. In 1990 and other census years, 80 percent or more of white women ages 25-55 who are not in the labor force are married, and over 60 percent are married with children. Further, the corresponding fractions of married women in the labor force are always

\footnotetext{
${ }^{5}$ See footnote 1 page 334.
} 
smaller. Thus, married women make up a disproportionate share of white women who do not engage in market work. However, this is not always true among black women. In 1980, married women made up 50 percent of the black female labor force but only 48 percent of black female non-participants. In 1990, married women accounted for 42 percent of the black female labor force and only 36 percent of black female non-participants. Also, among black women, the fraction of non-participants who were single mothers grew each decade, and by 1990, the modal non-participant in the black sample was a single mother. This trend in part reflects that fact that single motherhood among black women increased dramatically from 1960 to 1990 . However, the fraction of participants who were single mothers did not rise as rapidly over this period. In both 1980 and 1990, single mothers are over-represented in the samples of black women who do not work outside the home. In contrast, white single mothers in 1980 and 1990 constitute 12 percent of the white female labor force and less than 10 percent of white women who are not seeking employment.

Taken as a whole, the patterns in Tables 1 and 2 illustrate that, among white women, married women with children are least likely to choose market work, while among black women in recent decades, single mothers are least likely to choose market work. Many theories of marriage markets imply that adults who are not married possess less human capital than adults who are married. ${ }^{6}$ Further, Neal (2001) outlines a model where it is not only true that married women are more skilled than single women, but it is also true that single women with children who receive government aid are less skilled than single women who are childless. Because asset restrictions and high marginal tax rates on earned income often accompany government aid, single mothers who participate in these programs may be revealing that their potential wages are relatively low. In NLSY data, most black, single mothers who do not work outside the home are, in fact, receiving means-tested, government assistance in some form. Thus, even though the overall participation rates for black and white women are quite similar in 1990, racial differences in the composition of those who do not work suggest that measured racial wage gaps among women may still be contaminated by selection bias.

\footnotetext{
${ }^{6}$ See Becker (1981) and Lam (1988) for examples.
} 


\section{Comparisons Between the NLSY and Census Samples.}

In the analyses of wages that follow, I restrict my attention to samples that include only black and white women. Samples from the 1990 Census and March CPS include all women who were between 25 and 33 at the time of their census interview. The NLSY sample includes persons born between 1957 and 1964. At the time of their 1990 NLSY interviews, they were ages 25-33 as well. I include persons from the NLSY oversample of blacks, but I do not include persons from the supplemental samples of Hispanics, economically disadvantaged whites or military personnel. My NLSY sample should be nationally representative within race categories. ${ }^{7}$ Below, I highlight comparisons between results from the NLSY and census data, but I also include some results from the March CPS to provide other points of comparison. I used the NLSY data on grades completed and degrees received to compute an education variable that would closely mimic the coding of education in the 1990 Census, and I found that, within each race-gender cell, the NLSY and census data yield very similar average education levels. ${ }^{8}$

The first three panels of Table 3 document the availability of wage data in the three data

${ }^{7}$ The respondents come from two portions of the NLSY: (I) a nationally representative cross-section sample and (ii) a supplemental sample of black respondents that is representative of the black population. Attrition rates in the NLSY are low, but as a robustness check, I performed all the analyses for this paper using the 1990 sampling weights. The results are quite similar, but one must note that this weight is designed to adjust the 1990 samples but not the samples constructed from multiple interview years.

In the analyses presented here, I use the information on race and ethnicity in the NLSY to construct indicators for white and black that match those used in census data as closely as possible. Thus, some of the white respondents from the NLSY are identified as Hispanic according to their sample identification numbers (SID). Further, some persons who are nonblack and non-Hispanic according to their (SID) are not classified as white because they also report being Asian, a separate race category in the 1990 Census.

${ }^{8}$ Although average education levels within race-gender cells are almost identical in the two data sets, the education distributions are not exactly the same. For both black and white women, the census data record fewer women with no post-secondary schooling. In census data, .50 of black women and .43 of white women fall in the high school or less category, while the comparable figures are .59 and .54 in the NLSY. Rates of college completion are more similar in the two data sets. 
sets. $^{9} \quad$ The numbers in panels A-C of Table 3 are the fractions of each sample that worked during the survey period. For the Census and March CPS samples, this period includes the entire 1989 calendar year. For the NLSY sample, this period covers the time since the last interview.

Several patterns stand out in Table 3. First, in every sample, the fraction working increases with education level. Further, this pattern in more pronounced among black women. While the fraction working among college educated black women is over .9 in each of the three samples and always above the comparable rate for white women, the fraction working among black women with 12 years of schooling or less is only .57 in the census sample. This is well below the rate of .67 for white women in the same education group. ${ }^{10}$ Because education is an important observed determinant of wages, this pattern provides more evidence that selection patterns among white women differ in important ways from those observed among black women.

Second, note that the NLSY data provide more complete wage records. The fraction working is .72 among black women in the census but .79 among black women in the NLSY. The corresponding increase among white women is from .78 to .83 . Thus, compared to figures from census data, rates of working in the NLSY are higher and racial differences in these rates are slightly smaller. The NLSY is a panel survey that, in each year, involves extensive questions concerning employment and work histories. The repeated nature of the survey and its more extensive treatment of employment issues and time use provide additional opportunities to gather information about jobs that may be seasonal, occasional, or part-time.

Panels D-F provide information about the distribution of average hourly wages and the average of log hourly wages in the three data sets. Several results are noteworthy. First, wage

\footnotetext{
${ }^{9}$ I restrict the samples to persons with valid education data in 1990. Further, I eliminate employed individuals for whom it is not possible to calculate an hourly wage because information on earnings or labor supply is not available. I also eliminate a small number of workers who report combinations of hours worked and income earned that imply wages less than $\$ 1$ or more than $\$ 100$ per hour.

${ }^{10}$ This result is not driven by racial differences in composition within the "high school or less". Both rates of working fall as one examines lower schooling levels within this category, but the black rate always remains well below the comparable white rate.
} 
rates are generally higher in census data than in the NLSY or CPS. ${ }^{11}$ However, these differences are most striking among black workers. Whether measured by black-white ratios or black-white gaps in log wages, the NLSY data imply the highest levels of racial wage inequality among women. For example, the black-white wage ratio in the NLSY is .82. The comparable figures from the Census and CPS are .92 and .86 respectively.

Table 4 provides results based on NLSY data taken from the period 1988-92. By collecting data from a five-year period, it is possible to obtain valid wages for 90 percent of black women and over 94 percent of white women at some point during this period. ${ }^{12}$ Here, the wage measure is the average reported wage over the 1988-92 surveys. The black-white wage ratio remains at .82 for this sample. However, the estimated black-white gap in log wages, which is -.17 in the 1990 NLSY sample, increases slightly in absolute value to .18. Given that the 198892 sample contains valid wages for over 90 percent of women regardless of race, one might conclude that -.18 must be a good approximation of the true black-white wage gap among women in the 25-33 age range. However, noteworthy racial differences in patterns of selection remain.

To begin, in the 1988-92 sample, college educated black women are more likely to work than college educated white women while, among women with no post-secondary schooling, black women are notably less likely to work than white women. Panel C of Table 4 provides one

${ }^{11}$ The levels are not exactly comparable because the NLSY data refer to the most recent job as of the 1990 interview while the census data provide average wages in 1989. Some of the most recent jobs in the NLSY occurred in 1989, but on average, the wage rates in the NLSY refer to a later time period. Thus, one expects a small bias toward higher wage levels in the NLSY.

${ }^{12}$ This sample is 3.8 percent larger than the 1990 NLSY sample. The 1988-92 includes all individuals who report valid wage data or a clear report of non-employment during the 198892 period. There are employed persons in 1990 who are not included in the Table 3 analyses because they have missing or invalid wage data, and some of these persons either report valid wages or report non-employment in other years between 1998-92. I have performed all the analyses that follow using only the respondents with valid data in the 1990 sample. The results are very similar. Results concerning participation rates, mean wage gaps and wage ratios are almost identical. Median black-white log wage gaps among women, based on 1988-92 data, are roughly .01 bigger in absolute value in a sample restricted to women with valid 1990 data. This is true with or without the use of various imputations described below. 
measure of how significant these differences are. This table is similar to the one above, but the entries are average predicted log wages. I regressed the log of average wages over the period 1988-92 on indicator variables for age and years of schooling. I ran separate regressions by race and, based on the estimated coefficients, constructed predicted log wages for all women in both the black and white samples. The overall black-white gap in predicated log wages is -.19. This change is small but in the expected direction.

Table 5 illustrates other black-white differences in patterns of selection that may be more important. Table 5 provides descriptive statistics on sources on income for women. The statistics are presented separately by race, and the samples are divided according to whether or not women report market work. Statistics are presented for both 1990 and the 1988-92 period. The contrast between black women who do and do not participate is striking. Ten percent of black women in the NLSY sample did not work between 1988 and 1992. Of these women, 78 percent received SSI, AFDC, and/or Food Stamp payments in each year between 1988 and 1992. Among black women who worked at least once during this period, the corresponding number is .15. Further, black women who did not work over this period averaged 4.28 years of aid receipt. Among black women who did work over this period, the corresponding average is only 1.33. The pattern is reversed with respect to receipt of spousal income. Among black women who did not work from 1988-1992, only 4 percent were receiving spousal income in each year. The corresponding number is 15 percent among those who did work.

In contrast, among white women who do not work during the 1988-1992 period, 51 percent received spousal income in each year and only 26 percent government assistance in each year. The corresponding percentages among participants are 41 and 2 respectively. Although receipt of public assistance in more common among non-participants in both the black and white samples, the overall patterns suggest that non-participation in the white sample is associated with spousal support while non-participation in the black sample is associated with receiving public assistance.

Note that the 78 percent figure for aid receipt among black non-participants represents almost 8 percent of the entire black sample. If one is willing to assume that women who receive government aid over a long period, while not working outside the home, face relatively low 
potential wages, then it is possible that the missing wage data associated with these women may significantly affect measures of average wages among black women. However, over one percent of women in the white sample also report receiving aid in each year between 1988-92 while not working in the market. Thus, if one imputes wages for long-term welfare recipients, average wages for both black and white women will be affected. The following section illustrates the potential impacts of such imputations and assesses their overall impacts on measured blackwhite wage gaps among women.

\section{Imputations and Implied Wage Gaps}

Here, I conduct several exercises that involve wage imputations. The vast majority of the imputations involve women who satisfy four criteria. They must have no post-secondary education. They must have reported no market work during the 1988-92 period. They must have received government aid in every year from 1988-92, and they must have received no spousal support over this period. These women are long-term welfare recipients with low levels of education and no support from a spouse. It seems likely that they choose to accept the asset restrictions and income tests associated with government aid programs, in part, because they face poor labor market opportunities. Given imputations for these women, I can compute wage averages based on samples that include at least 95 percent of white respondents and 97 percent of black respondents. In the median regression models below, I also impute wages for a group of women who are quite different from long-term aid recipients. In the median regression models, I impute high wages for college educated women who did not work over the entire period 1988-92 but did receive substantial income support from their spouse. The definition of "substantial" support is spelled out below.

Table 6 provides the wage distributions implied by various imputation rules for the wages of long term aid recipients with no post-secondary schooling and no spousal support. The NLSY data provide few wage observations for women who are comparable with respect to sources of income and education level. There are 36 black women who (I) work in one year and only one year between 1998 and 1992 (ii) receive government aid in each year from 1988 to 1992 (iii) received no support from a spouse and (iv) have no post-secondary schooling. The mean wage 
among these women is $\$ 4.50$ per hour. There are 10 white women who satisfy these conditions. They earn an average of $\$ 4.71$ per hour. ${ }^{13}$ I assume that the wage offers of observationally similar women who never worked over the 1988-92 period are likely equal to or below these average wages. I conduct simulations using these wage averages as imputed values for the wages of observationally similar women who never work during the 1988-92 period, and I also conduct simulations with imputed wages equal to $90 \%, 75 \%$, and $50 \%$ of these averages.

The imputations have modest effects on the black-white wage ratio. The ratio based on observed wages between 1988 and 1992 is .82. Even if I impute a wage equal to $50 \%$ of the measured wages among long-term aid recipients that work at least one year, the black-white wage ratio does not fall below .79. However, the estimated black-white log wage gap is more sensitive to the imputation rule. The estimated gap based on observed wages during the 1988-92 period is -.18. The estimated gaps under the various imputation rules range from -.2 to -.24.

For comparison, recall the results in Table 3. Based on 1990 wage data available in the Census, CPS, and NLSY, black-white log wage gaps among women ages 25-33 are -.11, -.15, and -.17 respectively. Thus, if one takes the measured gap in census data as a starting point, the combination of higher yearly coverage rates in the NLSY, additional wage information from adjacent years, and the imputations based on income sources create implied black-white gaps in potential log wages that are roughly twice the measured gap among working women in a census cross-section. Even if one takes the -.17 figure from the 1990 NLSY cross-section as a baseline, the calculations involving various imputations imply increases of roughly 20 to 40 percent.

Further, the numbers in Table 6 may slightly understate the magnitude of black-white gaps in wage offers among women. Even though this table employs observed or imputed wages for all but three percent of the black sample and less than five percent of white women, the remaining samples of black and women are quite different. Almost 60 percent of the remaining black women report receiving aid in at least two years, while the comparable figure among white

${ }^{13}$ I could obtain larger samples by including all women who worked at least one year and satisfied the remaining criteria concerning education and income sources. In this case, the average wage in a sample of 136 black women would be $\$ 4.56$ and the average wage among 31 white women would be $\$ 5.16$. 
women is less than 20 percent. Further, many of the white women who do not work over the 1988-92 period are quite wealthy in terms of family income. Of the 119 white women who are not included in Table 6, 30 are married to men who make more than $\$ 45,000$ per year. Among white males ages $25-35$ in the 1990 census, $\$ 45,000$ is at roughly the $90^{\text {th }}$ percentile in the distribution of personal income. The decision not to work outside the home among women who are married to men earning such high incomes may signal high wealth and not low wages. In contrast, there is only one women in the black sample who did not work outside the home over the 1988 -92 period but did report spousal income above $\$ 30,000$ per year. This earnings level denotes the $90^{\text {th }}$ percentile in the income distribution for black men ages 25-35.

An alternative approach involving imputations is to assess black-white inequality using median black-white wage gaps. Median regression is an attractive alternative in contexts where one can be confident that missing wage data fall completely on one side of the median regression function. In this context, one can assign arbitrarily low or high values for the missing wages and the results from the median regression will be the same regardless of the specific value of the imputed wages. ${ }^{14}$

The top panel of Table 7 describes results for women who report working during the previous year in their 1990 interview. The first three sets of results correspond to data from the Census, CPS, and the 1990 NLSY respectively. In the NLSY, the median black-white log wage gap holding age constant is -.18. The estimated gaps in the Census and CPS are -.11 and -.16 respectively. These estimated gaps are quite similar to the mean gaps reported in Table 3. The final set of results includes all women who worked at least once during the 1988-92 period. Here, I use only one wage observation per person. I do not average wages over the 1988-92 period. For persons with no reported wage in 1990, I use the wage reported in the interview that occurred closest to January, 1990. In the sample of women who report a valid wage at some point over the 1988-92 period, the gap widens to -.21, almost twice the size of the gap based on

${ }^{14}$ See Johnson, Kitamura, and Neal (2000) for more details. The condition that justifies the imputations does differ depending on the covariates that are in the models. It must be the case that potential wages associated with missing wage data fall below the median regression function for the entire sample. Thus, regression functions that include education require a more stringent assumption than those that only include age variables. 
census wages.

The bottom panel of Table 7 presents results that involve imputed wages based on three different imputation rules. Rule 1 designates an hourly wage of one dollar for the group of long term aid recipients described in Table 6 above. ${ }^{15}$ Rule 2 follows rule 1 and in addition assigns a wage of $\$ 30$ per hour to all women who (I) did not work in the market over the 1988-92 period (ii) have at least a high school education and (iii) report average spousal earnings over the 198892 period that place their husbands above the $90^{\text {th }}$ percentile in the personal income distribution for men age 25-35 of the same race. Rule 3 is similar to rule 2 but uses the $75^{\text {th }}$ percentile in the male income distribution as a cutoff.

The results are not highly sensitive to the various imputation rules, and the estimated median gaps in Table $7 \mathrm{~b}$ include observed or imputed wages for almost 97 percent of black women and over 95 percent of white women. If one treats the wage offers associated with the women in the remaining portions of the black and white samples as random draws for their respective wage offer distributions, the imputation exercises described in Table $7 \mathrm{~b}$ imply that the overall median black-white gap in log wage is roughly $-.25 .{ }^{16}$ In absolute value, this figure represents almost a $40 \%$ increase over the -.18 figure derived from the sampling of working women in the 1990 NLSY, and it is over twice as large as the median gap among working

${ }^{15}$ Wage rates are low among black women who report a valid wage in at least one of the 1988-92 surveys but also report no post-secondary schooling, receiving aid in all years, and receiving no income from a spouse. Roughly 95 percent of these women make less than the median wage among employed black women in 1990.

${ }^{16}$ Among the 41 black women and 68 white women who are not included in the calculations for Table $7 \mathrm{~b}$ - Rule 3, the average years on welfare is much higher for black women and the average years of spousal support is much higher for white women. Thus, the gaps reported in Table $7 \mathrm{~b}$ may well understate the absolute value of the black-white gap in log median wages.

I computed bounds on the median gap reported under Table $7 \mathrm{~b}$ - Rule 3 by using two different additional imputation rules. First, I estimated a median regression on the full sample by imputing wages of one dollar per hour to these 41 black women and wages of $\$ 30$ per hour to the 68 white women. Then, I reversed the imputations and estimated the model again. Conditional on indicator variables for age, the estimated black-white median log wage gaps are -.319 and -.216 respectively. 
women in census data.

Appendix Table 2 presents parallel results for men. However, in this case, I explore the role of imputations in the CPS and census data as well. Here, I assign a wage of $\$ 1$ per hour to men ages 25-33 who report no market work over an entire year. The estimated median gaps based only on working men follow the same pattern observed among women. The estimated gap in census data is -.22 which is smaller than the corresponding gaps of -.29 in CPS data, and -.33 in NLSY data. However, given the $\$ 1$ per hour imputations for those who do not work, the results are more similar among the three data sets. The estimated median gaps, given these imputations, range from .33 to .37 in absolute value. Given a common method of correcting for selection bias, the estimated median black-white log wage gap among men in census data is much closer to the corresponding gap in the NLSY. ${ }^{17}$

\section{Marriage Markets and Selection Bias}

Table 3 shows a black-white log wage gap of -.11 and a black-white wage ratio of .92 among employed women ages 25-33 in 1990. Among women ages 25-55, black-white wage differences are even smaller and, and in 1980 census data, employed black women ages 25-55 actually report higher average wages than their white counterparts. ${ }^{18}$ Much of the existing literature interprets these data as evidence that racial differences in labor market opportunities among women are small, especially among women of similar education levels. As a result, racial differences in marriage market prospects and related differences in family income are the focus of much work on economic inequality among black and white women. However, large blackwhite differences in marriage market prospects should generate black-white differences in patterns of selection into market work, and these differences may systematically yield measured

${ }^{17}$ Johnson, Kitamura, and Neal (2000) provide evidence that some men who are not employed in a given year may face wage offers that are above the median wage given their characteristics. However, we also show that such cases are quite rare in samples restricted to men who report non-employment over multiple yearly interviews. Appendix Table 2 provides results based on the 1988-92 sample as well. Here, the implied gap is -.357.

${ }^{18}$ Among working women ages 25-55 in the 1990 and 1980 census, the black-white wage ratios are .97 and 1.08 respectively. 
black-white wage gaps that overstate the standing of black women relative to white women in terms of labor market opportunities. This point is easily demonstrated when one considers samples of black and white women who have the same labor force participation rates and do in fact face the same distributions of potential wages. In this setting, one should not expect employed black women to earn the same average wage as employed white women, but rather that employed black women will earn more than their white counterparts.

Consider a world with two populations of $\mathrm{N}$ women each. Every woman in population $\mathrm{A}$ (white) has a counterpart in population B (black) who possesses the exact same skill endowment. ${ }^{19}$ Therefore, assuming no discrimination for the moment, the distribution of market wage offers for women in group A is identical to the distribution in group B. Further, women in both groups live in the same political jurisdiction and therefore face the same taxes and have access to the same transfer programs. Assume that regardless of race, each woman receives one offer of marriage from a potential mate. Even though black and white women enjoy the same opportunities outside marriage, assume that the marriage market for white women strictly dominates the marriage market for black women. In particular, assume that each white woman receives an offer of marriage from a man whose market wage exceeds the market wage of any man who is proposing to any black woman who shares the white woman's same skill endowment.

Now, consider a pair of women, one black and one white, who possess the same skill endowment. If both choose not to marry, they will make the same labor supply decisions because they have the same endowments and face the same constraints. Thus, among any black-white pair that make different labor supply decisions, we know that at least one of the women is married, and further, we know that either both women are married or only the white woman is married, since the white woman in each pair receives a marriage proposal from a man with higher market earning potential. Thus, if a white woman does not work outside the home and her

${ }^{19}$ Signing the direction of the selection bias on estimated wage gaps requires a more complicated set of conditions when the two populations of interest face distributions of wage offers that are substantially different. However, the example presented here is an efficient tool for making key points about how differences in marriage market prospects affect differences in selection patterns. 
black counterpart does, the white woman must be married, and if the pattern is reversed and a black woman works at home while her white counterpart works in the market, it is not only clear that the white woman must be married but also that the black woman must be single. If both women are married and possess the same skill endowment, and the black woman does not work, then the white woman, who shares a common potential wage and has a husband who commands a higher market wage, will not work either. ${ }^{20}$ Thus, two potential sources of differential selection by race exist. There may be married white women who do not work even though equally skilled black women choose to work, and there may also be single black women who do not work even though equally skilled white women do. Appendix 3 demonstrates that, under common assumptions about household formation and time allocation within households, this group of single black women who work at home will, on average, enjoy lower wage offers than the afore mentioned group of married white women who work at home. ${ }^{21}$ Given this result, similar labor force participation rates among black and white women are not a sign that selection bias is not a problem but rather a guarantee that black-white wage gaps among working women will not accurately reflect black-white gaps in potential wages. Recall that the distribution of black and white potential wages is the same in this example. Thus, if the same fraction of black and white women chose to work at home, but white women who remain at home enjoy better potential market wages than their black counterparts, measured black-white wage gaps will indicate a labor market advantage for black women even though none exists. This result holds given numerous possible patterns of marriage and labor supply decisions. Married white women who do not work may enjoy higher or lower potential wages than married white women who do, and the same is true among married black women. In addition, regardless of race there is no requirement that women who do not work have potential wages that are on average greater or less than the wages of working women.

${ }^{20}$ This result is standard in models of household labor supply if leisure is a normal good and there are no strong complementarities between the home time of husbands and wives that offset the usual income and substitution effects.

${ }^{21}$ The result requires that preferences and technologies generate assortative mating in marriage markets and that the allocation of time to tasks among husbands and wives reflects patterns of comparative advantage. 
This example provides a potential explanation for the finding that, within education or skill groups, many data sets indicate that working black women earn significantly more per hour than their white counterparts. ${ }^{22}$ Consider a group of women who all share the same skills and professional background and assume that, within this group, the fractions working are the same. In the absence of discrimination, these two groups of women should face similar distributions of potential wages. But, if white women in the group enjoy better marriage prospects, the example above shows that working black women should receive higher wages than working white women. Black-white wages gaps among working women may suggest labor market advantages for black women relative to white women even when none exist. Further, one could easily construct examples, in which, racial differences in selection patterns mask the effects of discrimination.

And, this is not the only reason that it is particularly difficult to measure the effects of racial discrimination among women. At all skill and education levels, black men work less than white men. If one assumes these differences and the resulting differences in wage growth are entirely due to employment discrimination, one can isolate the effects of market discrimination on wages at a given age by conditioning on a measure of skills that pre-dates market entry. ${ }^{23}$ But, this line of reasoning is not helpful in the case of women. Among the well-educated and highly skilled, black women work more than white women. Further, it seems far fetched to assume that this differential reflects discrimination in favor of black women. It seems more likely that these differences reflect the fact that educated white women are more wealthy than their black

${ }^{22}$ Census and CPS data from 1980 indicate that college-educated black women earn more than their white counterparts. Further, in regression models that include controls for education and cognitive skill, data from the High School and Beyond Survey of 1980 and the NLSY often indicate that working black women earn more than working white women. A recent report by the National Center for Education Statistics, Jacobson et al (2001), finds that among young adult women with similar prior academic achievement, black women from two NCES data sets actually earn from 85 cents to a dollar more per hour than their white counterparts.

${ }^{23}$ Neal and Johnson (1996) focus on men in the NLSY and argue that racial wage gaps among men that began their adulthood with the same basic skill levels, as measured by AFQT scores, may be interpreted as upper bounds on the cumulative effects of labor market discrimination. 
counterparts because they enjoy better marriage market prospects. ${ }^{24}$ In such a setting, one might observe black women earning higher wages than white women who share the same age, education level and AFQT scores, and this differential would not be evidence of preferential treatment for black women, but rather the result of more accumulated work experience per year of potential experience. Note that this problem persists even if a given data set provides complete information on the potential wages of all women at a given point in time.

This paper addresses a rather straightforward measurement question. Among adult women in a specific age range, how much do average potential wages differ by race? More work is required to decompose these racial gaps into meaningful components.

\section{Changes In The Gap Over Time}

A large literature examines how differences between black and white men in employment rates may contaminate measures of black-white wage gaps among men. Much of this literature is concerned with adjusting measures of the change in the black-white wage gap over time for changes in patterns of selection into work by race. Similar issues may arise when studying changes in black-white wage inequality among women. Table 8 provides results from the March 1999 CPS that parallel those in Table 3 for the March 1990 CPS. The black-white wage gap among working women actually increased slightly over the $1990-99$ period. Some might conclude based on these data that, during the 1990s, the labor market prospects of black women relative to white women held constant or declined slightly. However, there are also noteworthy differences between the 1990 and 1999 data on participation. In the March 1990 CPS, 70 percent of white women with no post-secondary schooling worked at some point during the past calendar year. The comparable figure among black women with no post-secondary schooling was only 63 percent. However, in 1999, the pattern is reversed. Black women with no college schooling now work more than their white counterparts by a margin of 70 to 67 percent. Further, the fraction of college-educated white women who work fell slightly over the 1990s while the opposite is true among college-educated black women.

${ }^{24}$ Early work on female labor supply pointed to racial differences in marriage markets as a contributing factor to racial differences in women's labor supply. Cain (1966) is an example. 
The above analyses of the black-white wage gap among women in 1990 raises the possibility that a full analysis of changes in selection patterns over the past decade might reveal that black-white gaps in wage offers among women actually narrowed over the decade, even though wage data from working women indicate a small increase in the gap. While a full analysis of this topic is beyond the scope of this paper, it is clear that, over the past five years, welfare reforms and rising real wages among men may have affected the selection patterns of black and white women in different ways. ${ }^{25}$

\section{Conclusion}

My estimates of median black-white gaps in log potential wages among men and women in the NLSY imply that the black-white wage gap among women is more than two-thirds as large as the black-white wage gap among men. However, the standard in the existing literature is to adjust estimated black-white wage gaps among men for racial differences in selection and to ignore selection issues when estimating the same gaps among women. Depending on the specific data source, this practice would lead one to the very different conclusion that the black-white gap in log potential wages is at least twice as large and maybe three times as large among men as among women. Yet, such a conclusion raises an obvious question. How could black men reach adulthood and face racial wage gaps that are more than twice as large as those faced by the young women who grew up beside them in their families and neighborhoods? The NLSY data show that the black-white gap in years of school completed is only slightly larger among men than women, and the black-white AFQT score gap among women is over one standard deviation and quite close in magnitude to the gap observed among men. Further, data from NAEP math tests given to $12^{\text {th }}$ graders over the 1990 s indicate that achievement gaps remain significant between

\footnotetext{
${ }^{25}$ A recent Bureau of Labor Statistics Report, http://stats.bls.gov/newsrels.htm/famee.txt, indicates that, the number of married women with infant children who choose to stay home with young children increased each year from 1997 through 2000. The same report indicated that labor force participation among comparable unmarried mothers rose by 13 percentage points between 1994 and 1998 and has held steady for 1999 and 2000. The BLS report does not break these numbers out by race, but it is possible and even likely, that black and white women do not contribute equally to these changes. These are the types of changes in selection behavior that could directly impact measured wage black-white wage gaps among women.
} 
black and white students regardless of gender. ${ }^{26}$ Based on these human capital measures, it is not easy to understand how the black-white gap in potential wages among men could be two or three times larger than the comparable gap among women.

Similar issues arise when considering measured black-white gaps in the 1980 Census. According to the United States Commission on Civil Rights, wage comparisons among black and white women within the South show that employed black women in the South earned 5.4 percent more than their white counterparts. How could this statistic be an accurate measure of overall black-white differences in potential wages in the South at that time? In 1980, adult black women in the South reported an average of one year less schooling than white women, and according to all evidence, most southern blacks had attended schools that were inferior to those attended by their white counterparts. ${ }^{27}$ I contend that scholars must engage in a great deal of creative story telling to rationalize the belief that, in the South in 1980, black women enjoyed better labor market opportunities than white women. Given the pending release of more data from the 2000 census, government agencies may soon report that the labor market opportunities of black women have declined relative to those of white women over the last two decades. Much work will be required to evaluate such a claim, but if it is made, one must seriously ask whether or not racial gaps in labor market opportunities among women were ever as small as they appeared to be some two decades ago.

${ }^{26}$ Cook \& Evans (2000) report significant improvement in the black-white test score gaps during the 1970s and 1980s. However, the past decade did not produce substantial narrowing of the gap.

${ }^{27}$ See Chapter 4 of The Economic Status of Black Women by the United States Commission on Civil Rights (1990). Card and Krueger (1992) provide evidence on the relative quality of black schools for different birth cohorts. 
Table 1: Female Labor Force Participation by Race, 1960-1990

\begin{tabular}{cccccc}
\hline & \multicolumn{3}{c}{ Black } & & \multicolumn{2}{c}{ White } \\
\cline { 2 - 3 } \cline { 5 - 6 } & In Labor Force & $\begin{array}{c}\text { Worked Full- } \\
\text { Time }\end{array}$ & & In Labor Force & Worked Full- \\
\hline 1960 & 0.52 & 0.20 & & 0.39 \\
1970 & 0.58 & 0.27 & & 0.47 & 0.19 \\
1980 & 0.66 & 0.38 & 0.61 & 0.22 \\
1990 & 0.73 & 0.46 & & 0.73 & 0.33 \\
\hline
\end{tabular}

The samples include women between 25 and 55 years of age. "In Labor Force" refers to status at the time of census interview. "Worked Fulltime" refers to persons who worked at least 35 hours in the survey week and worked at least 48 weeks in the previous calendar year. 
Table 2a: Family Structure for Female Black Labor Force Participants and NonParticipants, 1960-1990

\begin{tabular}{|c|c|c|c|c|c|c|c|c|}
\hline & \multicolumn{4}{|c|}{ In Labor Force } & \multicolumn{4}{|c|}{ Not in Labor Force } \\
\hline & \multicolumn{2}{|c|}{ With Child } & \multicolumn{2}{|c|}{ Without Child } & \multicolumn{2}{|c|}{ With Child } & \multicolumn{2}{|c|}{ Without Child } \\
\hline & Married & Single & Married & Single & Married & Single & Married & Single \\
\hline 1960 & 0.35 & 0.18 & 0.22 & 0.24 & 0.55 & 0.14 & 0.20 & 0.11 \\
\hline 1970 & 0.43 & 0.24 & 0.15 & 0.18 & 0.50 & 0.25 & 0.14 & 0.12 \\
\hline 1980 & 0.40 & 0.31 & 0.10 & 0.19 & 0.38 & 0.36 & 0.10 & 0.16 \\
\hline 1990 & 0.33 & 0.35 & 0.09 & 0.24 & 0.28 & 0.43 & 0.08 & 0.21 \\
\hline
\end{tabular}

Full-Time, Full-Year

With Child

Without Child

Married Single

$0.23 \quad 0.30$

0.19

0.23

0.30

0.15

0.21

0.10

0.20

0.10

0.25

0.33
Not Full-Time, Full-Year

\section{With Child}

Without Child

Married Single Married Single

$\begin{array}{llll}0.49 & 0.15 & 0.21 & 0.15\end{array}$

0.49

0.24

0.14

0.13

0.40

0.34

0.09

0.16

0.31

0.40

0.08

0.21

Table 2b: Family Structure for Female White Labor Force Participants and Non-

Participants, 1960-1990

\begin{tabular}{|c|c|c|c|c|c|c|c|c|}
\hline & \multicolumn{4}{|c|}{ In Labor Force } & \multicolumn{4}{|c|}{ Not in Labor Force } \\
\hline & \multicolumn{2}{|c|}{ With Child } & \multicolumn{2}{|c|}{ Without Child } & \multicolumn{2}{|c|}{ With Child } & \multicolumn{2}{|c|}{ Without Child } \\
\hline & Married & Single & Married & Single & Married & Single & Married & Single \\
\hline 1960 & 0.48 & 0.09 & 0.23 & 0.21 & 0.77 & 0.03 & 0.16 & 0.04 \\
\hline 1970 & 0.54 & 0.10 & 0.21 & 0.16 & 0.77 & 0.04 & 0.15 & 0.04 \\
\hline 1980 & 0.51 & 0.12 & 0.20 & 0.18 & 0.72 & 0.06 & 0.16 & 0.06 \\
\hline 1990 & 0.47 & 0.12 & 0.20 & 0.22 & 0.65 & 0.09 & 0.17 & 0.09 \\
\hline
\end{tabular}

Full-Time, Full-Year

Not Full-Time, Full-Year

\begin{tabular}{cccccccccc} 
& \multicolumn{2}{c}{ With Child } & \multicolumn{2}{c}{ Without Child } & & \multicolumn{2}{c}{ With Child } & \multicolumn{2}{c}{ Without Child } \\
& Married & Single & Married & Single & & Married & Single & Married & Single \\
\hline 1960 & 0.36 & 0.10 & 0.26 & 0.28 & 0.72 & 0.04 & 0.17 & 0.06 \\
1970 & 0.43 & 0.11 & 0.24 & 0.22 & 0.73 & 0.05 & 0.16 & 0.06 \\
1980 & 0.41 & 0.13 & 0.23 & 0.23 & 0.68 & 0.08 & 0.16 & 0.09 \\
1990 & 0.39 & 0.13 & 0.22 & 0.26 & 0.62 & 0.10 & 0.17 & 0.12 \\
\hline
\end{tabular}

See notes to Table 1 for sample description. 
Table 3

1990 Labor Force Statistics from Census, March CPS, and NLSY: Women Ages 25-33

Panel A: Fraction Who Worked in Past Calendar Year: 1990 Census

\begin{tabular}{|c|c|c|c|c|}
\hline & \multicolumn{4}{|c|}{ Education Level } \\
\hline & High School or Less & Some College & College + & All Levels \\
\hline Black & .57 & .83 & .94 & .72 \\
\hline$[\mathbf{N}]$ & {$[8,129]$} & {$[5,844]$} & {$[2,262]$} & {$[16,235]$} \\
\hline White & .67 & .82 & .90 & .78 \\
\hline$[\mathbf{N}]$ & {$[51,015]$} & {$[39,277]$} & {$[28,778]$} & {$[119,070$} \\
\hline \multicolumn{5}{|c|}{ Panel B: Fraction Who Worked in Past Calendar Year: 1990 March CPS } \\
\hline & \multicolumn{4}{|c|}{ Education Level } \\
\hline & High School or Less & Some College & College + & All Levels \\
\hline Black & .63 & .84 & .95 & .74 \\
\hline$[\mathbf{N}]$ & {$[728]$} & {$[365]$} & {$[160]$} & {$[1,253]$} \\
\hline White & .70 & .81 & .90 & .78 \\
\hline$[\mathbf{N}]$ & {$[4,821]$} & {$[2,446]$} & {$[2,195]$} & {$[9,462]$} \\
\hline
\end{tabular}

Panel C: Fraction Who Worked since last Interview: 1990 NLSY

\begin{tabular}{cccc|c}
\hline & \multicolumn{4}{c}{ Education Level } \\
\cline { 2 - 5 } & High School or Less & Some College & College + & \multicolumn{2}{c}{ All Levels } \\
\hline Black & .71 & .88 & .96 & .79 \\
{$[\mathrm{~N}]$} & {$[755]$} & {$[383]$} & {$[146]$} & {$[1,284]$} \\
White & .78 & .87 & .91 & .83 \\
{$[\mathrm{~N}]$} & {$[1217]$} & {$[509]$} & {$[525]$} & {$[2,251]$} \\
\hline
\end{tabular}

All three samples include women who report that they are not working as well as women who report information on earnings and labor supply required to compute an hourly wage. Employed women with missing earnings or labor supply data as well as women whose implied hourly wage is less than 1 dollar or more 100 dollars per hour are excluded. The CPS means are weighted using the March Supplemental Weight. 
Table 3 continued

Panel D: Average Wages by Race and Education level - 1990 Census

Education Level

\begin{tabular}{ccccccc|ccc} 
& \multicolumn{2}{c}{ High School or Less } & \multicolumn{2}{c|}{ Some College } & \multicolumn{2}{c|}{ College +} & \multicolumn{2}{c}{ All Levels } \\
\cline { 2 - 9 } & wage & log wage & wage & log wage & wage & log & wage & log \\
& & & & & & & wage & & wage \\
\hline Black & 7.22 & 1.78 & 8.89 & 2.04 & 11.93 & 2.36 & 8.77 & 1.99 \\
(Std. Dev.) & $(6.24)$ & $(.59)$ & $(6.12)$ & $(.53)$ & $(6.24)$ & $(.49)$ & $(6.41)$ & $(.59)$ \\
White & 7.47 & 1.86 & 9.31 & 2.09 & 12.70 & 2.42 & 9.58 & 2.10 \\
$($ Std. Dev.) & $(5.33)$ & $(.54)$ & $(5.56)$ & $(.53)$ & $(6.90)$ & $(.51)$ & $(6.25)$ & $(.57)$ \\
\hline Ratio/Gap & .97 & -.08 & .95 & -.05 & .94 & -.06 & .92 & -.11 \\
\hline
\end{tabular}

Panel E: Average Wages by Race and Education level - 1990 March CPS

\begin{tabular}{|c|c|c|c|c|c|c|c|c|}
\hline & \multicolumn{6}{|c|}{ Education Level } & & \\
\hline & \multicolumn{2}{|c|}{ High School or Less } & \multicolumn{2}{|c|}{ Some College } & \multicolumn{2}{|c|}{ College +} & \multicolumn{2}{|c|}{ All Levels } \\
\hline & wage & log wage & wage & log wage & wage & $\begin{array}{c}\text { log } \\
\text { wage }\end{array}$ & wage & $\begin{array}{c}\text { log } \\
\text { wage }\end{array}$ \\
\hline Black & 6.52 & 1.73 & 7.94 & 1.93 & 11.99 & 2.32 & 7.91 & 1.90 \\
\hline (Std. Dev.) & (4.12) & $(.54)$ & (5.28) & $(.53)$ & (9.44) & $(.56)$ & (6.00) & $(.58)$ \\
\hline White & 7.21 & 1.83 & 9.14 & 2.06 & 12.25 & 2.38 & 9.15 & 2.05 \\
\hline (Std. Dev.) & $(4.40)$ & $(.54)$ & $(5.90)$ & $(.55)$ & $(6.53)$ & $(.52)$ & $(5.87)$ & $(.59)$ \\
\hline Ratio/Gap & .87 & -.10 & .87 & -.13 & .98 & -.06 & .86 & -.15 \\
\hline
\end{tabular}


Table 3 continued

Panel F: Average Wages by Race and Education level - 1990 NLSY

\begin{tabular}{|c|c|c|c|c|c|c|c|c|}
\hline & \multicolumn{6}{|c|}{ Education Level } & & \\
\hline & \multicolumn{2}{|c|}{ High School or Less } & \multicolumn{2}{|c|}{ Some College } & \multicolumn{2}{|c|}{ College +} & \multicolumn{2}{|c|}{ All Levels } \\
\hline & wage & log wage & wage & log wage & wage & $\begin{array}{c}\text { log } \\
\text { wage }\end{array}$ & wage & $\begin{array}{c}\log \\
\text { wage }\end{array}$ \\
\hline Black & 6.34 & 1.74 & 8.05 & 2.00 & 10.81 & 2.31 & 7.53 & 1.91 \\
\hline (Std. Dev.) & (3.27) & (.46) & (3.44) & (.43) & (4.07) & (.38) & (3.77) & $(.48)$ \\
\hline White & 7.42 & 1.88 & 9.48 & 2.14 & 12.33 & 2.41 & 9.17 & 2.08 \\
\hline (Std. Dev.) & (3.79) & $(.51)$ & (4.57) & $(.49)$ & (5.77) & $(.48)$ & (4.99) & $(.54)$ \\
\hline Ratio/Gap & .85 & -.14 & .84 & -.14 & .88 & -.10 & .82 & -.17 \\
\hline
\end{tabular}

The numbers in parentheses are the standard deviation of wages or log wages in particular samples. The sample sizes are easily derived from the information in Tables 3A-3C. All black-white differences in cell means for a given column, in any of the Tables 3D-3F, are statistically significant. See Appendix 1 for details concerning the construction of key variables. The CPS means are weighted using the March Supplemental Weight. 
Table 4

Results Based on NLSY Data for Years 1988-92

Women Born 1957-64

Panel A: Fraction Who Worked During 1988-92 Period

\begin{tabular}{cccc|c}
\hline & \multicolumn{4}{c}{ Education Level } \\
\cline { 2 - 5 } & High School or Less & Some College & College + & \multicolumn{2}{c}{ All Levels } \\
\hline Black & .84 & .97 & 1 & .90 \\
{$[N]$} & {$[772]$} & {$[397]$} & {$[152]$} & {$[1321]$} \\
White & .91 & .96 & .97 & .94 \\
{$[N]$} & {$[1268]$} & {$[534]$} & {$[547]$} & {$[2349]$} \\
\hline
\end{tabular}

Panel B: Average Wages by Race and Education level - 1988-92

Education Level

\begin{tabular}{cccccc|cc}
\hline \multicolumn{2}{l}{ High School or Less } & \multicolumn{2}{c}{ Some College } & \multicolumn{2}{c|}{ College +} & \multicolumn{2}{c}{ All Levels } \\
\hline wage & log wage & wage & log wage & wage & log & wage & $\begin{array}{c}\text { log } \\
\text { wage }\end{array}$ \\
\hline 5.99 & 1.72 & 8.10 & 2.01 & 10.57 & 2.27 & 7.26 & 1.88 \\
$(2.53)$ & $(.38)$ & $(3.55)$ & $(.41)$ & $(4.54)$ & $(.43)$ & $(3.57)$ & $(.44)$ \\
7.09 & 1.86 & 9.36 & 2.14 & 12.17 & 2.41 & 8.84 & 2.06 \\
$(3.33)$ & $(.45)$ & $(4.07)$ & $(.44)$ & $(5.10)$ & $(.43)$ & $(4.51)$ & $(.50)$ \\
\hline .84 & -.14 & .87 & -.13 & .87 & -.14 & .82 & -.18 \\
\hline
\end{tabular}


Table 4 continued

Panel C: Predicted Log Wages by Race and Education level - 1988-92

\section{Education Level}

\begin{tabular}{|c|c|c|c|c|}
\hline & High School or Less & Some College & College + & All Levels \\
\hline & log wage & log wage & log wage & log wage \\
\hline Black & 1.70 & 2.01 & 2.27 & 1.86 \\
\hline (Std. Dev.) & (.13) & (.09) & $(.06)$ & $(.23)$ \\
\hline White & 1.86 & 2.14 & 2.41 & 2.05 \\
\hline (Std. Dev.) & $(.10)$ & $(.10)$ & (.08) & $(.25)$ \\
\hline Ratio/Gap & -.15 & -.13 & -.14 & -.19 \\
\hline
\end{tabular}

The samples sizes for Table 4A are slightly larger than those for Table 3A. There are 1321 black women and 2349 white women in Table 4A. The 1988-92 data include all individuals who report valid wage data or a clear report of non-employment during the 1988-92 period. There are employed persons in 1990 who are not included in the Table 3 analyses because they have missing or invalid wage data, and some of these persons either report valid wages or report non-employment in other years between 1998-92. 
Table 5: Sources of Income and Education-NLSY, 1988-1992

(Standard Deviations in Parentheses)

\begin{tabular}{|c|c|c|c|c|c|c|}
\hline & $\begin{array}{c}\text { Years } \\
\text { of } \\
\text { Govt. } \\
\text { Aid }\end{array}$ & $\begin{array}{l}\text { Years of } \\
\text { Spousal } \\
\text { Income }\end{array}$ & $\begin{array}{c}\text { Fraction } \\
\text { with } 5 \\
\text { Years of } \\
\text { Aid }\end{array}$ & $\begin{array}{c}\text { Fraction with } 5 \\
\text { Years of Spousal } \\
\text { Income }\end{array}$ & $\begin{array}{c}\text { Years } \\
\text { of } \\
\text { School }\end{array}$ & $\begin{array}{c}\text { Number of } \\
\text { Obs. }\end{array}$ \\
\hline \multicolumn{7}{|l|}{ Black Women } \\
\hline 1990 Participants & $\begin{array}{c}1.03 \\
(1.69)\end{array}$ & $\begin{array}{c}1.48 \\
(1.95)\end{array}$ & 0.10 & 0.15 & $\begin{array}{l}13.1 \\
(1.9)\end{array}$ & 1009 \\
\hline $\begin{array}{l}1990 \text { Non- } \\
\text { Participants }\end{array}$ & $\begin{array}{c}3.88 \\
(1.81)\end{array}$ & $\begin{array}{c}0.64 \\
(1.52)\end{array}$ & 0.64 & 0.07 & $\begin{array}{l}11.5 \\
(1.9)\end{array}$ & 275 \\
\hline $\begin{array}{l}\text { 1988-92 } \\
\text { Participants }\end{array}$ & $\begin{array}{c}1.33 \\
(1.90)\end{array}$ & $\begin{array}{c}1.40 \\
(1.94)\end{array}$ & 0.15 & 0.15 & $\begin{array}{l}13.0 \\
(1.9)\end{array}$ & 1187 \\
\hline $\begin{array}{l}\text { 1988-92 Non- } \\
\text { Participants }\end{array}$ & $\begin{array}{c}4.28 \\
(1.53)\end{array}$ & $\begin{array}{c}0.38 \\
(1.17)\end{array}$ & 0.78 & 0.04 & $\begin{array}{l}11.0 \\
(1.9)\end{array}$ & 134 \\
\hline \multicolumn{7}{|l|}{ White Women } \\
\hline 1990 Participants & $\begin{array}{l}0.30 \\
(.94)\end{array}$ & $\begin{array}{c}2.89 \\
(2.11)\end{array}$ & 0.01 & 0.40 & $\begin{array}{l}13.4 \\
(2.3)\end{array}$ & 1869 \\
\hline $\begin{array}{l}1990 \text { Non- } \\
\text { Participants }\end{array}$ & $\begin{array}{c}1.22 \\
(1.93)\end{array}$ & $\begin{array}{c}3.37 \\
(\mathbf{2 . 0 0})\end{array}$ & 0.16 & 0.51 & $\begin{array}{l}12.3 \\
(2.3)\end{array}$ & 382 \\
\hline $\begin{array}{l}\text { 1988-92 } \\
\text { Participants }\end{array}$ & $\begin{array}{c}0.39 \\
(1.09)\end{array}$ & $\begin{array}{c}2.94 \\
(2.09)\end{array}$ & 0.02 & 0.41 & $\begin{array}{l}13.3 \\
(2.3)\end{array}$ & 2204 \\
\hline $\begin{array}{l}\text { 1988-92 Non- } \\
\text { Participants }\end{array}$ & $\begin{array}{c}1.56 \\
(2.18)\end{array}$ & $\begin{array}{c}3.14 \\
(2.20)\end{array}$ & 0.26 & 0.51 & $\begin{array}{l}12.1 \\
(2.4)\end{array}$ & 145 \\
\hline
\end{tabular}

Participants in 1990 are respondents who report a valid wage for the current or most recent job. 1988-92 participants must report a valid wage for this variable in at least one of the survey years between 1988 and 1992. Non-participants for the 1988-92 period report that they have not worked since their last interview in each of their interviews between 1988-92. Women who receive income from AFDC, SSI, or Food Stamps make up the recipients of government aid category. 
Table 6 :

Average Wages and Log Wages Given Imputations for Long-Term Welfare Recipients:

$W_{\text {impute }}=$ Avg. Wage for Welfare Recipients Who Worked in Only One Year (1988-1992)

Average Wages

\begin{tabular}{|c|c|c|c|c|c|c|c|c|}
\hline & \multicolumn{2}{|c|}{$\mathbf{W}_{\text {impute }}$ (see note) } & \multicolumn{2}{|c|}{$W_{\text {impute }} * .9$} & \multicolumn{2}{|c|}{$W_{\text {impute }} * .75$} & \multicolumn{2}{|c|}{$W_{\text {impute }} * .5$} \\
\hline & $\mathbf{E} \leq \mathbf{1 2}$ & Total & $\mathbf{E} \leq \mathbf{1 2}$ & Total & $\mathbf{E} \leq \mathbf{1 2}$ & Total & $\mathbf{E} \leq \mathbf{1 2}$ & Total \\
\hline Black & 5.80 & 7.06 & 5.75 & 7.03 & 5.67 & 6.98 & 5.53 & 6.90 \\
\hline (Std. Dev.) & (2.42) & (3.51) & (2.46) & (3.54) & $(2.52)$ & (3.58) & (2.67) & (3.67) \\
\hline White & 7.04 & 8.80 & 7.03 & 8.79 & 7.01 & 8.78 & 6.99 & 8.77 \\
\hline (Std. Dev.) & (3.31) & (4.50) & (3.32) & $(4.51)$ & (3.34) & $(4.52)$ & (3.37) & $(4.53)$ \\
\hline Implied & 0.82 & 0.80 & 0.82 & 0.80 & 0.81 & 0.80 & 0.79 & 0.79 \\
\hline Ratio & & & & & & & & \\
\hline
\end{tabular}

Average Log Wages

\begin{tabular}{|c|c|c|c|c|c|c|c|c|}
\hline & \multicolumn{2}{|c|}{$W_{\text {impute }}$ (see note) } & \multicolumn{2}{|c|}{$W_{\text {impute }} * .9$} & \multicolumn{2}{|c|}{$W_{\text {impute }}{ }^{*} .75$} & \multicolumn{2}{|c|}{$W_{\text {impute }} * .5$} \\
\hline & $\mathbf{E} \leq \mathbf{1 2}$ & Total & $\mathbf{E} \leq \mathbf{1 2}$ & Total & $\mathbf{E} \leq \mathbf{1 2}$ & Total & $\mathbf{E} \leq \mathbf{1 2}$ & Total \\
\hline Black & 1.690 & 1.854 & 1.677 & 1.846 & 1.654 & 1.834 & 1.605 & 1.805 \\
\hline (Std. Dev.) & $(.361)$ & (.438) & (.369) & $(.445)$ & $(.390)$ & $(.460)$ & $(.462)$ & $(.508)$ \\
\hline White & 1.853 & 2.054 & 1.851 & 2.052 & 1.847 & 2.050 & 1.838 & 2.045 \\
\hline (Std. Dev.) & (.448) & (.498) & $(.450)$ & $(.500)$ & $(.454)$ & $(.503)$ & (.469) & $(.512)$ \\
\hline Implied & -0.16 & -0.20 & -0.17 & -0.21 & -0.19 & -0.22 & -0.23 & -0.24 \\
\hline Gap & & & & & & & & \\
\hline
\end{tabular}

The samples include 1278 black women and 2230 white women. The table presents descriptive statistics based on a sample that includes imputed wages for women who (I) did not work between 1988 and 1992 (ii) did not receive support from a spouse during this period (iii) reported no post-secondary schooling and (iv) received government aid in each year from 1988-92. The imputations are based on average wages observed among groups of women who are similar on all these dimensions except that they did work and report a valid wage in one and only one of the survey years 1988-92. These averages are computed separately for black and white women. In 1990 dollars, this imputed wage, $\mathrm{W}_{\text {impute }}$, equals $\$ 4.71$ among white women and $\$ 4.50$ among black women. Samples that include these imputed wages provide wage observations for .95 of the white sample and .97 of the black sample. 
Table 7a

Median Regression Results for Women

\begin{tabular}{|c|c|c|c|c|c|c|c|c|}
\hline \multirow[b]{2}{*}{ Black } & \multicolumn{2}{|c|}{ Census 1990} & \multicolumn{2}{|c|}{ CPS 1990} & \multicolumn{2}{|c|}{ NLSY 1990} & \multicolumn{2}{|c|}{ NLSY 1988-1992 } \\
\hline & $\begin{array}{c}-.11 \\
(.006)\end{array}$ & $\begin{array}{c}-.07 \\
(.003)\end{array}$ & $\begin{array}{c}-.16 \\
(.024)\end{array}$ & $\begin{array}{c}-.13 \\
(.021)\end{array}$ & $\begin{array}{c}-0.18 \\
(0.024)\end{array}$ & $\begin{array}{c}-0.15 \\
(0.022)\end{array}$ & $\begin{array}{c}-.21 \\
(.019)\end{array}$ & $\begin{array}{c}-.16 \\
(.022)\end{array}$ \\
\hline Schooling & - & $\begin{array}{c}.13 \\
(.001)\end{array}$ & - & $\begin{array}{c}.12 \\
(.004)\end{array}$ & - & $\begin{array}{c}0.11 \\
(0.007)\end{array}$ & - & $\begin{array}{c}.12 \\
(.006)\end{array}$ \\
\hline $\mathbf{N}$ & 104,089 & 104,089 & 8,206 & 8,206 & 2,878 & 2,878 & 3,391 & 3,391 \\
\hline
\end{tabular}

Table 7b

Median Regression Results with Imputations

\begin{tabular}{lcccccc}
\hline & \multicolumn{3}{c}{ Rule 1 } & \multicolumn{2}{c}{ Rule 2 } & \multicolumn{2}{c}{ Rule 3 } \\
\hline Black & -.248 & -.188 & -.249 & -.188 & -.260 & -.196 \\
& $(.028)$ & $(.021)$ & $(.026)$ & $(.022)$ & $(.026)$ & $(.024)$ \\
Schooling & & & & & & .131 \\
& & .129 & -132 & $(.006)$ & & $(.007)$ \\
$\mathrm{N}$ & 3,508 & 3,508 & 3,539 & 3,539 & 3,561 & 3,561 \\
\hline
\end{tabular}

Specification A includes indicator variables for age. Specification B includes indicator variables for potential experience levels and years of school completed. The CPS analyses are weighted using the March Supplemental Weight.

Rule 1 - Impute a wage of one dollar for all long term aid recipients with no post secondary schooling and no spousal support who do not report market work over the 1988-92 interviews..

Rule 2 - Rule 1 plus impute $\$ 30$ per hour for all white women with at least a high school education and spousal support averaging over $\$ 45,000$ per year. Also, impute $\$ 30$ per hour for black women who have at least a high school education and average spousal support of $\$ 30,000$ dollars per year.

Rule 3 - Rule 2 except lower the spousal support cutoffs to $\$ 32,000$ for white women and $\$ 21,000$ for black women. 


\section{Table 8}

\section{Results for Women in March 1999 CPS}

Panel A: Fraction Who Worked in Past Calendar Year: 1999 Census

\begin{tabular}{|c|c|c|c|c|}
\hline & \multicolumn{4}{|c|}{ Education Level } \\
\hline & High School or Less & Some College & College + & All Levels \\
\hline Black & .70 & .86 & .95 & .80 \\
\hline$[\mathbf{N}]$ & {$[342]$} & {$[262]$} & {$[133]$} & [737] \\
\hline White & .67 & .81 & .88 & .78 \\
\hline$[\mathbf{N}]$ & {$[2334]$} & {$[1638]$} & {$[1690]$} & {$[5662]$} \\
\hline
\end{tabular}

Panel B: Average Wages by Race and Education level - 1999 March CPS

\section{Education Level}

\begin{tabular}{ccccccc|ccc} 
& \multicolumn{2}{c}{ High School or Less } & \multicolumn{2}{c|}{ Some College } & \multicolumn{2}{c|}{ College +} & \multicolumn{2}{c}{ All Levels } \\
\cline { 2 - 10 } & wage & log wage & wage & log wage & wage & log & wage & log \\
& & & & & & & wage & & wage \\
\hline Black & 8.23 & 1.94 & 10.32 & 2.23 & 14.81 & 2.60 & 10.41 & 2.19 \\
(Std. Dev.) & $(6.20)$ & $(.54)$ & $(4.88)$ & $(.48)$ & $(6.38)$ & $(.45)$ & $(6.22)$ & $(.56)$ \\
White & 9.37 & 2.09 & 11.35 & 2.31 & 16.33 & 2.67 & 12.48 & 2.36 \\
(Std. Dev.) & $(6.04)$ & $(.54)$ & $(6.14)$ & $(.49)$ & $(9.07)$ & $(.51)$ & $(7.90)$ & $(.57)$ \\
\hline Ratio/Gap & .88 & -.15 & .91 & -.08 & .91 & -.07 & .83 & -.17 \\
\hline
\end{tabular}

These tables present results that parallel those in Tables 3B and 3E. The data come from the March 1999 CPS. The means are weighted using the March Supplemental Weight. 


\section{APPENDIX 1}

I construct race variables for NLSY data that parallel the race definitions in census data. The black indicator is straightforward. However, the white indicator requires information from two variables. The NLSY respondents, as part of questions about all family members in the respondent's household, provide information about race and ethnicity. The white sample used in this paper includes persons who report being white but do not report being of Asian ancestry.

The hourly wage variables for the NLSY come from the created variables "Hourly Rate of Pay at Current or Most Recent Job." These variables are created from answers to questions concerning earnings, time units for pay, and labor supply. In both the Census and CPS, I create an hourly wage variable. I divide total wage income for 1989 by an estimate of total hours worked based on answers to questions about weeks worked and usual hours worked per week. In all three data sets, I eliminate individuals who report information that implies hourly wage rates below $\$ 1$ per hour or above $\$ 100$ per hour. In the NLSY data, I use the CPI-U to transform all wage observations to 1990 dollars.

In the NLSY, the education variables reflect a combination of information. I use data from the created variable "High Grade Completed as of May 1" as well as information on degrees received. I assign twelve years of schooling to persons with only eleven years of schooling completed who also complete their GED. I also assign 16 years of school completed to persons who report a college degree with only 15 years of schooling, and I assign fifteen years of schooling to those who report 16 years but do not report a college degree. I implement these changes to create an education variable that will more closely resemble the 1990 Census education variable, which is based on degrees rather than simply years attended. In the Census data, I eliminate a small sample of cases where the respondent reports no schooling at all. This response is not credible given the age of the sample in 1990, and the persons in this group do not report average wages and weeks worked that are consistent with having no schooling at all.

The aid receipt variables in Table 5 come from monthly histories that describe AFDC, SSI, and Food Stamp income. The spousal income measures come from a series of questions that document spousal income from various sources in the previous calendar year. I sum income from salary, military pay, and selfemployment income to get total spousal income support.

All of the analyses involving CPS data employ the March Supplemental weight. The NLSY and Census analyses are unweighted. 


\section{Appendix 2}

Estimated Median Black-White Log Wage Gaps for Men

\begin{tabular}{|c|c|c|c|c|c|c|c|c|c|c|c|c|c|c|c|c|}
\hline & \multicolumn{4}{|c|}{ Census } & \multicolumn{4}{|c|}{ CPS } & \multicolumn{8}{|c|}{ NLSY } \\
\hline & \multicolumn{2}{|c|}{1990} & \multicolumn{2}{|c|}{$\begin{array}{c}1990 w / \\
\text { Imputations }\end{array}$} & \multicolumn{2}{|c|}{1990} & \multicolumn{2}{|c|}{$\begin{array}{c}1990 w / \\
\text { Imputations }\end{array}$} & \multicolumn{2}{|c|}{1990} & \multicolumn{2}{|c|}{$\begin{array}{c}1990 w / \\
\text { Imputations }\end{array}$} & \multicolumn{2}{|c|}{ 1988-1992 } & \multicolumn{2}{|c|}{$\begin{array}{c}\text { 1988-92 w/ } \\
\text { Imputations }\end{array}$} \\
\hline & $\mathbf{A}$ & B & $\mathbf{A}$ & B & $\mathbf{A}$ & B & $\mathbf{A}$ & B & $\mathbf{A}$ & B & $\mathbf{A}$ & B & $\mathbf{A}$ & B & $\mathbf{A}$ & B \\
\hline Black & -.223 & -.184 & -.332 & -.280 & -.291 & -.246 & -.373 & -.323 & -.329 & -.281 & -.372 & -.317 & -.346 & -.294 & -.357 & -.316 \\
\hline Schooling & - & .11 & - & .12 & - & .10 & - & .11 & - & .11 & - & .12 & & .10 & - & .10 \\
\hline $\mathbf{N}$ & \multicolumn{2}{|c|}{118,906} & \multicolumn{2}{|c|}{126,413} & \multicolumn{2}{|c|}{8,929} & \multicolumn{2}{|c|}{9,408} & \multicolumn{2}{|c|}{3,048} & \multicolumn{2}{|c|}{3,234} & \multicolumn{2}{|c|}{3,341} & \multicolumn{2}{|c|}{3,421} \\
\hline \multicolumn{17}{|l|}{ Fraction } \\
\hline \multicolumn{17}{|l|}{ Valid } \\
\hline Black & \multicolumn{2}{|c|}{.83} & \multicolumn{2}{|c|}{1} & \multicolumn{2}{|c|}{.88} & \multicolumn{2}{|c|}{1} & \multicolumn{2}{|c|}{.89} & \multicolumn{2}{|c|}{1} & \multicolumn{2}{|c|}{.96} & \multicolumn{2}{|c|}{1} \\
\hline White & \multicolumn{2}{|c|}{.95} & \multicolumn{2}{|c|}{1} & \multicolumn{2}{|c|}{.96} & \multicolumn{2}{|c|}{1} & \multicolumn{2}{|c|}{.97} & \multicolumn{2}{|c|}{1} & \multicolumn{2}{|c|}{.99} & & 1 \\
\hline
\end{tabular}

All men who did not work in the entire calendar year are assigned wages of $\$ 1$ per hour in the imputations. Specification A includes indicator variables for age. Specification B includes indicator variables for potential experience levels and years of school completed. The CPS analyses are weighted using the March Supplemental Weight. 


\section{APPENDIX 3 - MARRIAGE MARKETS AND SELECTION PATTERNS}

Consider two marriage markets, A and B. Each market contains $\mathrm{N}$ men and $\mathrm{N}$ women.

Let $\mathrm{w}_{\mathrm{ij}}=$ the potential market wage for the ith woman in group $\mathrm{j}$, where $\mathrm{I}=1,2, . . \mathrm{N}$, and $\mathrm{j}=\mathrm{a}, \mathrm{b}$. Women in each group are ordered by their potential market wage. Thus,

$$
\mathrm{w}_{\mathrm{ij}}>\mathrm{w}_{\mathrm{i}-1 \mathrm{j}} \quad \forall \mathrm{I}=1,2 \ldots \mathrm{N}, \quad \mathrm{j}=\mathrm{a}, \mathrm{b} .
$$

The distribution of wages among women is the same in the two groups, i.e.

$$
\mathrm{w}_{\mathrm{ia}}=\mathrm{w}_{\mathrm{ib}} \quad \forall \quad \mathrm{I}=1,2 \ldots \mathrm{N} \text {. }
$$

Each woman receives a marriage proposal from one and only one man in her group, and potential mates are assortatively matched within each group. However, marriage market prospects for women in group A strictly dominate those for women in group $\mathrm{B}$. Thus, defining $\mathrm{e}_{\mathrm{ij}}$ as the market wage of the man who proposes to the ith woman in group $\mathrm{j}$,

$$
\mathrm{e}_{\mathrm{ia}}>\mathrm{e}_{\mathrm{ib}} \quad \forall \mathrm{I}=1,2 \ldots \mathrm{N} \text {. }
$$

Women calculate the indirect utility of marriage by solving for the allocations of leisure and consumption that they would enjoy in marriage to their potential spouse. They compare this indirect utility with the maximum utility available either through participation in a government assistance program or through living alone with no external source of support. Women maximize utility by choosing the best available combination of family structure and time allocation. To focus on the role of wages, assume that no woman or man in either market possesses non-earned income. All income other than labor market income comes through government programs. These programs may condition aid on realized earnings, but the government is not able to condition taxes or transfers aid on skill endowments or potential market wages. Further, assume that all persons of a given gender are equally productive in home production regardless of group membership. 
Given these assumptions consider any specification of preferences, household production technologies, and government programs such that the following four conditions hold:

$$
\frac{\partial^{2} \mathrm{TS}_{\mathrm{i}}}{\partial \mathrm{w}_{\mathrm{i}} \partial \mathrm{e}_{\mathrm{i}}}>0
$$

Here, I suppress group subscripts, and I use $\mathrm{TS}_{\mathrm{i}}$ to denote the total realized surplus in marriage between the ith woman and ith man in a marriage market. I assume that utility for both parties can be expressed in units of some numeraire good. Total Surplus (TS) is the difference between two sums: the sum of the each partner's utility level within marriage and the sum of the utility levels associated with each partner's outside option. A-1 guarantees that the surplus in marriage exhibits increasing returns to scale with respect to the skill endowments of the partners. This is a standard property of household models that involve collective consumption and efficient bargaining with marriage.

A-2) Bargaining within marriage is regular, i.e. if a change in endowments or technology causes the total surplus in a marriage to rise (fall), then the individual utilities of both partners will rise (fall).

A-3) If the ith woman in a given market is married, holding constant her potential wage $\mathrm{w}_{\mathrm{i}}$, the amount of time she spends in market work is a non-increasing function of her husband's potential wage $\mathrm{e}_{\mathrm{i} \cdot}{ }^{28}$

A-4) Among single women in a given marriage market, women who participate in market work have higher potential wages than single women who do not participate in the market.

Now define the following indicator variables:

$D_{i j}=1$ if the ith woman in group $\mathrm{j}$ works in the market.

$D_{i j}=0$ otherwise

$\mathrm{M}_{\mathrm{ij}}=1$ if the ith woman in group $\mathrm{j}$ is married.

$\mathrm{M}_{\mathrm{ij}}=0$ otherwise

${ }^{28}$ This result should hold if leisure is a normal good and there are no strong complementarities between husband and wife's leisure time or between their time allocations to home production. 
Proposition: Assume that there are group differences in the patterns of selection into work among women, i.e. for some $I,\left(D_{i a}=0, D_{i b}=1\right)$ and for some I', $\left(D_{i^{\prime} a}=1, D_{i^{\prime} b}=0\right)$. Given such differences, the average potential wage among women in group A who do not work will exceed the corresponding average in group B.

Proof:

For any $\mathrm{I}$, there are eight possible combinations of $\left(\mathrm{D}_{\mathrm{i} a}, \mathrm{M}_{\mathrm{i} a}, \mathrm{D}_{\mathrm{ib}}, \mathrm{M}_{\mathrm{ib}}\right)$ such that $\mathrm{D}_{\mathrm{i} a} \neq \mathrm{D}_{\mathrm{ib}}$. These combinations are the potential sources of selection differences between groups A and B at skill level I. Note that of these eight combinations, only three could arise as equilibrium outcomes given the conditions stated above. These three are

$$
\left(D_{i a}=1, M_{i a}=1, D_{i b}=0, M_{i b}=0\right)
$$

$$
\left(D_{i a}=0, M_{i a}=1, D_{i b}=1, M_{i b}=0\right)
$$

$$
\left(D_{\mathrm{ia}}=0, \mathrm{M}_{\mathrm{ia}}=1, \mathrm{D}_{\mathrm{ib}}=1, \mathrm{M}_{\mathrm{ib}}=1\right)
$$

To see that only these three remain, note that any combination involving $\left(M_{i a}=0, M_{i b}=0\right)$ must have $\left(D_{i a}=D_{i}\right.$ b ) since single women of the same rank face the same market wage offer and the same menu of government programs. Further, there can be no outcomes such that $\left(\mathrm{M}_{\mathrm{i} a}=0, \mathrm{M}_{\mathrm{ib}}=1\right)$ because the marriage market for women in A dominates the marriage market for women in group B. Finally, the combination $\left(D_{i a}=1, M_{i a}=1\right.$, $\mathrm{D}_{\mathrm{ib}}=0, \mathrm{M}_{\mathrm{ib}}=1$ ) is not possible because condition (A-3) requires that an increase in the husband's market wage cannot increase the wife's labor supply in the market.

Given the remaining three sources of differential selection described in P-1 through P-3, the wage offer for a pair of women described by P-1 must be less than the wage offer for women who satisfy P-2 since the group B women described in these pairs are both single, and only the one in P-2 participates in market work. See A-4 above. Further, the women in pair P-3 must enjoy a greater potential wage than the women in P-2, since the group B woman in P-3 is married, and group B woman in P-2 is not. Note that A-1 and A-2 together imply that all single persons have lower market wage offers than all married persons.

Thus, the group B women described in P-1 have lower potential wages than the group A women in P-2 and P-3. 


\section{References:}

Altonji, Joseph and Blank, Rebecca. "Race and Gender in the Labor Market" in Orley Ashenfelter and David Card, eds., Handbook of Labor Economics. Vol. 3, Amsterdam: North Holland, 1999.

Bayard, Kimberly, Judith Hellerstein, David Neumark, and Kenneth Troske, 1999, "Why Are Racial and Ethnic Wage Gaps Larger for Men than for Women? Exploring the Role of Segregation Using the New Worker-Establishment Characteristics Database," in Haltiwanger, Lane, Spletzer, Theeuwes, and Troske, Eds., The Creation and Analysis of Employer-Employee Matched Data (Amsterdam: Elsevier Science B.V.), pp. 175-203.

Blau, Francine and Beller, Andrea. "Black-White Earnings Over the 1970s and 1980s: Gender Differences in Trends" Review of Economics and Statistics, May, 1992, 74 (2), pp.276-86.

Brown, Charles. "Black-White Earnings Ratios since the Civil Rights Acts of 1964: The Importance of Labor Market Dropouts." Quarterly Journal of Economics, February 1984, 91(1), pp. 31-44.

Butler, Richard and Heckman, James J. "The Government's Impact on the Labor Market Status of Black Americans: A Critical Review," in L. Hausman, et al, eds. Equal Rights and Industrial Relations. Madison: Industrial Relations Research Assocation, 1977.

Card, David and Alan B. Krueger. "School Quality and Black-White Relative Earnings: A Direct Assessment." Quarterly Journal of Economics 107 (February 1992): 151-200.

Cain, Glen. Married Women in the Labor Force, University of Chicago Press, Chicago, 1966.

Chandra, Amitabh. "Labor Market Dropouts and the Racial Wage Gap: 1940-1990," American Economic Review. May, 2000. pp. 333-338.

Cook, Michael D. and William N. Evans "Families or Schools? Explaining the Convergence in White and Black Academic Performance.” Journal of Labor Economics. October, 2000. 18(4), pp. 729-754.

Heckman, James J., Lyons, Thomas, and Petra Todd, "Understanding Black-White Wage Differentials, 19601990" American Economic Review. May, 2000. pp. 344-349.

Neal, Derek “The Economics of Family Structure,” NBER Working Paper \#8519. October, 2001.

Neal, Derek and Johnson, William."The Role of Premarket Factors in Black-White Wage Differences." Journal of Political Economy, October 1996, 104(5), pp. 869-895.

Smith, James and Welch, Finis. "Black Economic Progress after Myrdal.” Journal of Economic Literature. June 1989, 27(2), pp. 519-564.

United States Commission on Civil Rights, The Economic Status of Black Women, October, 1990. 
